\title{
種の感受性分布を用いた農薬の生態リスク評価に関する研究
}

\author{
永井孝志* \\ 国立研究開発法人農業・食品産業技術総合研究機構農業環境変動研究センター
}

（2017年6月6日受理）

\section{Studies on ecological risk assessment of pesticide using species sensitivity distribution}

\author{
Takashi NAGAI \\ Institute for Agro-Environmental Sciences, NARO, 3-1-3 Kannondai, Tsukuba, Ibaraki 305-8604, Japan
}

Keywords: database, algae, arthropod, risk management.

\section{は じめに}

近年, 農薬等の不適切な使用によって生物多様性が劣化す る可能性が指摘されるようになり, 農林水産省では環境保全 型農業として農薬の使用等による環境負荷の軽減に配慮した 持続的な農業を推進している，現在の環境保全型農業におい ては，例えば慣行の栽培体系に比べて（化学合成）農薬の使 用を5割低減することによって, 特別栽培という表示が可能 となる。このように, 現時点の環境保全型農業では, 農薬使 用量（使用回数）の低減が優先的に行われているが，この科 学的根拠は薄弱である. 使用する農薬の種類毎にそれぞれリ スクの大きさは異なり，また同じ農薬であっても使用方法や 流出防止対策などによりリスクは変化する。 ところが, 現状 では農薬は使用回数のみで評価されるため, どんな農薬をど う使おうと同じ一回とカウントされる．生産現場では農薬の 使用をなる心゙く減らす努力を行っているが，例えば種子消毒 などの残留も少なく環境中への流出もない，つまり農薬使用 のリスクが低いと考えられる使用方法から減らしている例も ある，よって，農薬を減らす努力がそのままリスクの低減に

\footnotetext{
* \% 305-8604 茨城県つくば市観音台 3-1-3

E-mail: nagait@affrc.go.jp

(c) 日本農薬学会
}

貢献するとは限らない.

そもそも生態系保全を目的とした場合，低隇の対象は「農 薬使用量」ではなく，農薬使用に伴う「生態リスク」でなけ ればならない，過剩な減農薬の推進は農業生産のリスクを増 大させるため，本来の環境保全型農業の目的である「持続的 な農業生産」と矛盾する。したがって,「農薬の使用量を減 らす」,「ょり低毒性の農薬に切り替える」,「農薬の流出防止 対策をとる」などの様々な環境保全型農業の体系における, 生物多様性の保全効果と農業の生産性を定量的に解析してい く事が望ましい。このような情報が得られるようになれば, 農業生産への負の影響を抑え, 効率的にリスクを減らす対策 を主体的に選択することが可能となる。このようなリスク評 価は「解決指向リスク評価」として提案されており ${ }^{1)}$, 農薬 登録審査における「良いか悪いか」という二者択一のリスク 評価とは大きく思想が異なる。

リスクを定量的に表現するには確率論的リスク評価を行う のが有効である。これは，毒性や懪露などの様々な不確実性 を確率的に表現し, 環境中濃度が生物の毒性值を超過する確 率はどのくらいかを定量的に評価する方法である. Fig. 1 に 示した概念図では, 生物種による感受性の変動性と, 環境中 濃度（PEC）の地域差による変動性を考慮し，6生物種の感 受性と 5 地域の環境中濃度を総当たりで評価した場合の「環 境中濃度 $>$ 毒性值」になってしまう確率を表している. 30 


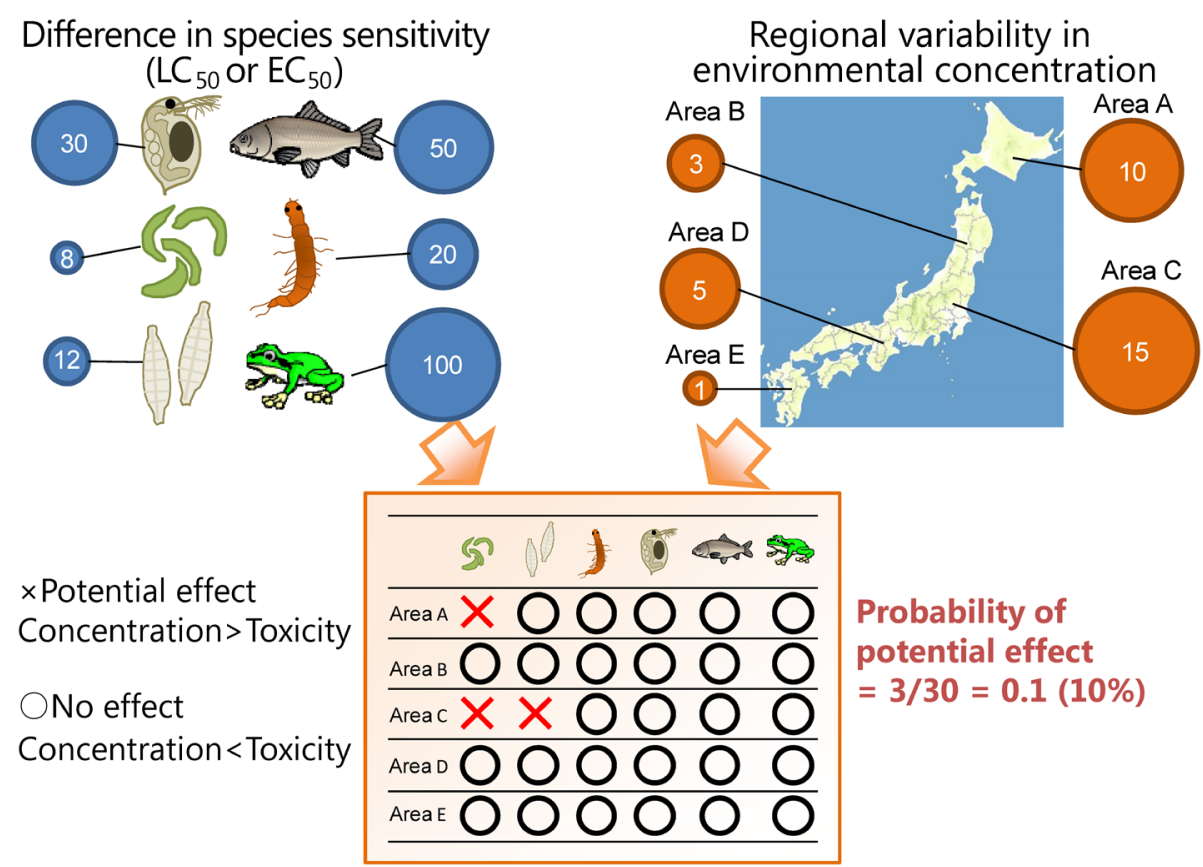

Fig. 1. Conceptual diagram of probabilistic ecological risk assessment.

通りの組み合わせのうち，3つの組み合わせで影響ありと なってしまうので, 影響を受ける確率は $3 / 30=10 \%$ というこ とになる。この確率の大小によって, 生態リスクの大きさを 相互比較できることになる。

本稿では, 確率論的リスク評価を行う際にキーとなる概 念となる種の感受性分布（Species Sensitivity Distribution, SSD）について解説し，その生態リスク評価における活用に ついて紹介する。

\section{1. 種の感受性分布}

\section{1. 感受性の種間差}

農薬取締法に基づく「水産動植物の被害防止に係る農薬登 録保留基準（以下，水産登録保留基準）」の適用の下，平成 17 年より新たな農薬の水産動植物に対するリスク評価に基 づいた基準值の設定が順次進められている ${ }^{2)}$. 現行の登録保 留基準において, 毒性に係る基準值は, 魚類（メダカ又はコ イ), ミジンコ (オオミジンコ), 藻類 (緑藻Pseudokirchneriella subcapitata）のいわゆる「3 点セット」の急性毒性試験 結果による $\mathrm{LC}_{50}$ (半数致死濃度) 值もしくは $\mathrm{EC}_{50}$ (半数影 響濃度）值を，それぞれの種間の感受性差に関する不確実係 数（魚類と甲殼類は基本 10 , 藻類は 1）で除したものの最小 值と設定される.

河川や湖沼などの水圈生態系には多種多様な生物が生息 しているが, 農薬の毒性は対象となる生物種によって極 端に異なることが知られている。ここで殺虫剂イミダク ロプリドの感受性種間差を例に挙げる。まず水産登録保 留基準值は，3種の毒性值（魚類 $\mathrm{LC}_{50}>105,000 \mu \mathrm{g} / \mathrm{L}$ ，甲
殼 類 $\mathrm{EC}_{50}=85,000 \mu \mathrm{g} / \mathrm{L}$, 藻 類 $\left.\mathrm{EC}_{50}>98,600 \mu \mathrm{g} / \mathrm{L}\right)$ よ , $85,000 / 10=8,500 \mu \mathrm{g} / \mathrm{L}$ と導出された ${ }^{2)}$. 次に既報文献から各 種の毒性值（ $\mathrm{LC}_{50}$ もしくは $\mathrm{EC}_{50}$ 值）をプロットすると Fig. 2 のようになり，登録保留基準の $8500 \mu \mathrm{g} / \mathrm{L}$ 遵守していても ほとんどの甲殼類や水生昆虫が影響を受けてしまうことにな る ${ }^{3)}$.オオミジンコは殺虫剤に対して基本的に感受性が高い が，常に高感受性であるわけではない。また，節足動物とい う分類群の中においても 10,000 倍以上もの種間の感受性差 があることは注目に值する。このようなことは「The myth of the most sensitive species (最も感受性が高い種という神

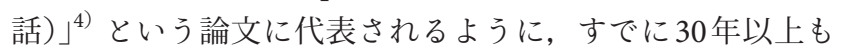
前から議論されている。

\section{2. 種の感受性分布 (Species sensitivity distribution)}

上記のような問題点が挙げられる中で, 水圏生態系に生息

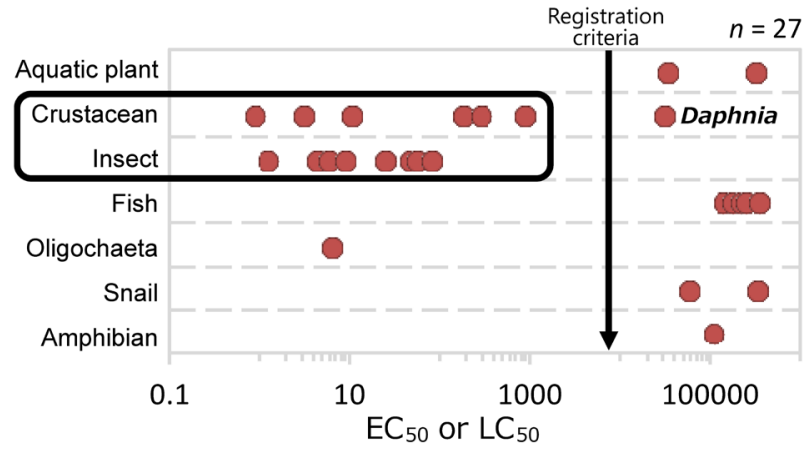

Fig. 2. Genus mean acute values of acute toxicity $\left(\mathrm{EC}_{50}\right.$ and $\mathrm{LC}_{50}$ ) of imidacloprid for each taxonomic group. 


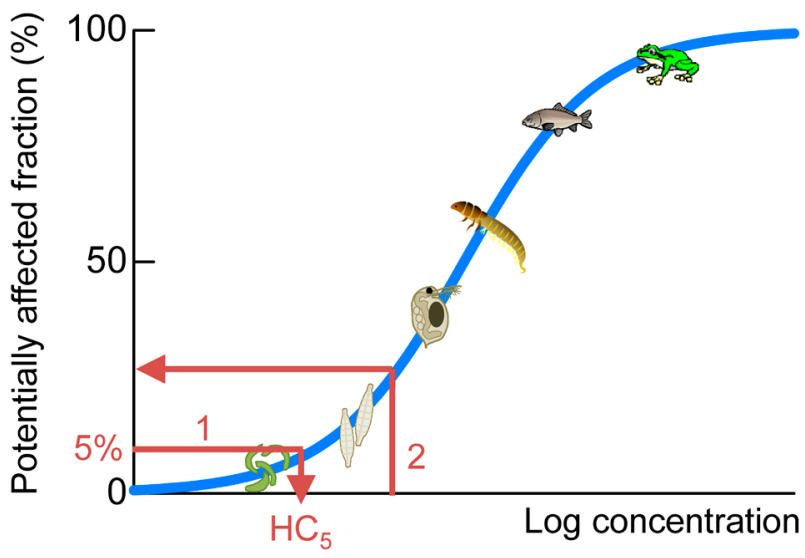

Fig. 3. Conceptual diagram of SSD. The variability of toxicity values $\left(\mathrm{EC}_{50}\right.$ or $\left.\mathrm{LC}_{50}\right)$ of 6 species is fitted to log-normal distribution. Arrow 1 indicates the derivation of $\mathrm{HC}_{5}$, and arrow 2 indicates the calculation of PAF from pesticide concentration.

するすべての種に対する毒性試験を行うことは現実的には不 可能である. その一方で, 多数の生物種の化学物質に対する 感受性は対数正規分布に適合することが経験的に知られて おり, Fig. 3 のうな累積確率分布として表現できる。この ような生物種間の感受性差を統計学的に表現したものがSSD である ${ }^{5)}$. SSD の解析を行うにはある一定数以上の毒性デー タが揃っている必要がある。そしてSSDの曲線は, 農薬の 濃度が上昇するにつれて影響を受ける生物種の割合が高く なっていくという関係を表現している。これを用いて，環 境中の農薬の濃度から「影響を受ける種の割合（potentially affected fraction, PAF)」を計算してこれをリスク指標とす る活用法と，95\%の種を保護する濃度（言い換えれば5\%の 種が影響を受ける濃度，5\% Hazard Concentration, $\mathrm{HC}_{5}$ ）を 推定してリスク管理の目標值とする活用法がある（Fig. 3). ここでは $\mathrm{LC}_{50}$ もしくは $\mathrm{EC}_{50}$ 值を超えた曝露を受けた場合に 「その種は農薬による影響を受けた」と定義する。この手法
は室内急性毒性試験をベースとしているため, 生態系管理の 目標である生物個体群の存続可能性などを評価しているわけ ではない.

各国の行政施策への導入例をみると，米国や欧州，オース トラリアなどにおいて， $\mathrm{HC}_{5}$ を予測無影響濃度とすること で，水生生物保全のための水質基準值の設定根拠として用 いている ${ }^{6-8)}$.これは，95\%以上の種を保護できれば，種の 多様性には大きな影響は無い，という仮定に基づいている. $\mathrm{HC}_{5}$ の值を予測無影響濃度とすることの妥当性については, 隔離実験水界を用いた模擬生態系試験（メソコスム・マイ クロコスム試験）との比較により, 様々な農薬について $\mathrm{HC}_{5}$ が打打む称安全側に立った評価となっていることが確認さ れている ${ }^{3,10-12)}$. また, 農薬登録の場面においては, 欧州で Regulatory Acceptable Concentration の導出のための高次評 洒法として活用されている ${ }^{13)}$.

SSD を農薬に適用する場合には, 除草剤では藻類やウキク サ等水生植物に対する毒性が特徵的に高いため, 一次生産者 とそれ以外で分布が分かれ，殺虫剤は節足動物に対する毒性 が特徵的に高いため, 節足動物とそれ以外で分布が分かれる

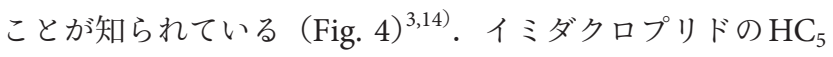
は $0.43 \mu \mathrm{g} / \mathrm{L}$ となり，水産登録保留基準值よりも 10,000 倍以 上低い值となった。

\section{2. 確率論的リスク評価法の開発}

\section{1 不確実性を考慮した農薬の確率論的生態リスク評} 価：除草剂シメトリンのケーススタディー

高度な生態リスク評価のためには, Fig. 1に示したように 毒性や曝露などの本来変動性を持つパラメータを一つに決定 せずに分布として表現し, 確率論的な評価を行うのが望まし いと考えられる.このような確率論的生態リスク評価は, 殺 虫剂ダイアジノン ${ }^{15)}$ とアルディカルブ16) の例, 除草剂アト ラジン ${ }^{17)}$ の例など多数報告されている.これらのリスク評
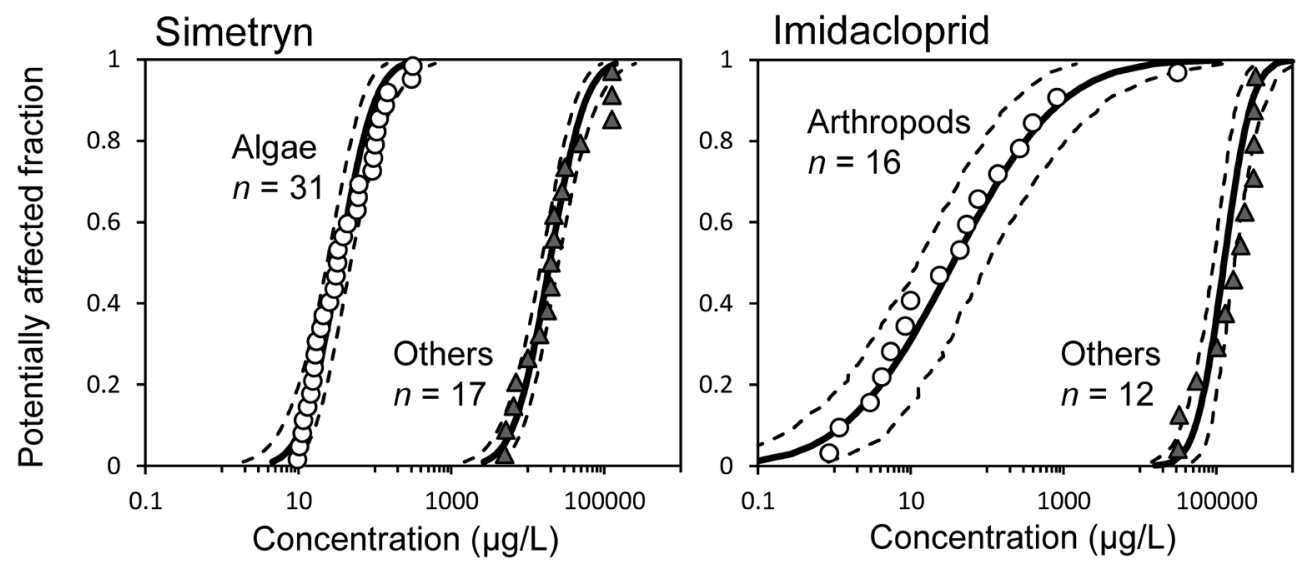

Fig. 4. Typical SSD curves for sensitive and insensitive taxonomic groups of freshwater organisms. Genus mean acute values and cumulative probabilities were plotted as the $x$-axis and $y$-axis, respectively. The maximum likelihood estimation (solid line) with the $90 \%$ confidence interval (dashed line) of log-normal distribution is shown. 

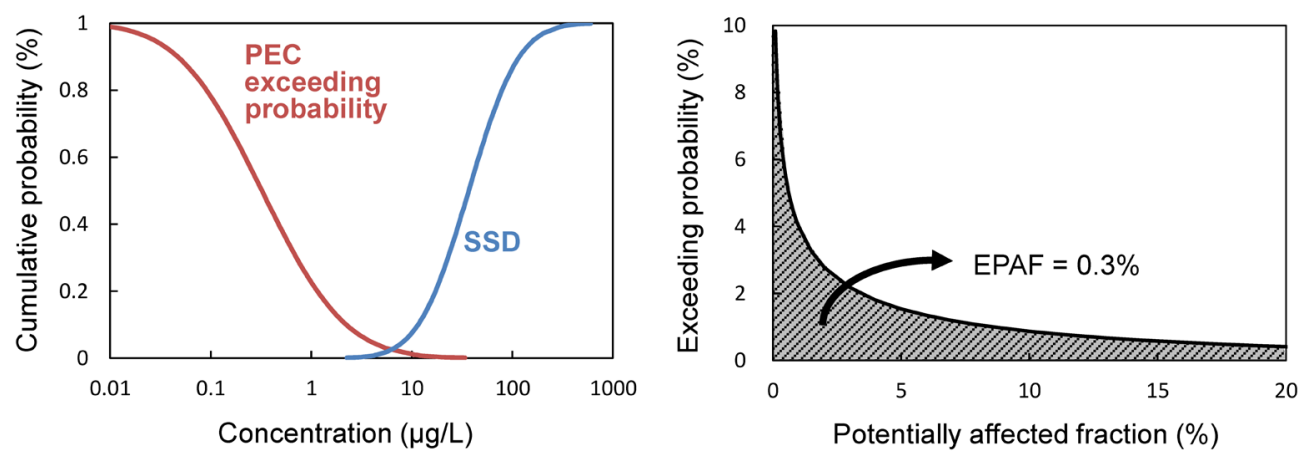

Fig. 5. Comparison of PEC distributions and SSD for freshwater algae (left) and joint probability curve (risk curve) for simetryn (right). Area under the curve (shaded area) means EPAF.

価では，任意の割合の種が影響を受ける確率としてリスクが 定量化される。

筆者の研究では手始めに除草剂シメトリンを対象とし, 毒 性評価や曝露評価の不確実性を分析することにより確率論 的な生態リスク評価手法を開発した ${ }^{14)}$. 毒性評価では, 文 献からシメトリンの生態毒性試験の結果を収集し, SSD解 析を行った. 31 属の淡水産藻類の $\mathrm{EC}_{50}$ 值を対数正規分布に 適合させ， $\mathrm{HC}_{5}$ を $8.2 \mu \mathrm{g} / \mathrm{L}$ と推定した（Fig. 4). 曝露評価で は，環境省によって定義された環境モデル中の PEC算定に 用いるパラメータ（流域内の水田率，河川比流量，農薬普及 率，土壤の比重や有機炭素含有率など）の変動を確率分布と して表現し, モンテカルロシミュレーションを用いてPEC の取りうるばらつきを解析した。 その結果, PECの平均值

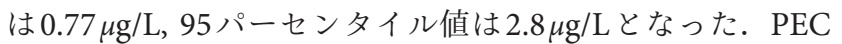
の分布とSSDの重なりから，ある割合の種が影響を受ける 濃度レベルの曝露を受ける確率を計算し, Joint Probability Curve（リスクカーブ，Fig. 5）として表現した. 結果とし て，5\%の種が影響を受ける確率は $1.5 \%$ と計算された。

\subsection{1 種の除草剤の生態リスク比較の事例}

水稲作がマイナーである欧米においては，水稲用除草剂の
リスク評価はこれまでほとんど行われていない，加えて，水 稲用農薬は灌溉用水を通じて水系に流出しやすいという特徴 を持ち, 畑作で用いる農薬に比べて水生生物に対するリス クは非常に大きいと考えられる。 シメトリンのケーススタ ディーにおいて, 日本における水稲用除草剤を対象とした確 率論的生態リスク評価の手法を開発したが，農薬の種類に よって得られるデータの質・量がばらばらであり，この手法 を用いて多くの農薬に対して横並びの評価を行い比較しょう とする場合の取り扱いに問題が残された。そこで次の研究で は，得られるデータの質・量がばらばらである代表的な水稲 用除草剂 11 種の確率論的生態リスク評価の手法論の検討を 行った ${ }^{18)}$. 既存のデータを最大限有効利用できる既存の推 定方法を複数組み合わせることにより，足りないデータを補 いながら横並びでリスクを評価する手法を構築し，これらの 有効性について考察した.

曝露の分布とSSDを組み合わせたリスクカーブ（Fig. 5) の下の面積を計算することで, 影響を受ける割合の期待值を 求め, これをEPAF（Expected Potentially Affected Fraction） と表現した。ここでの EPAFは，全国平均的にどのくらいの 割合の種か影響を受けるか，というリスクの定量的な指標と して意味付けられる. 各リスクの大きさに対応する地域毎の

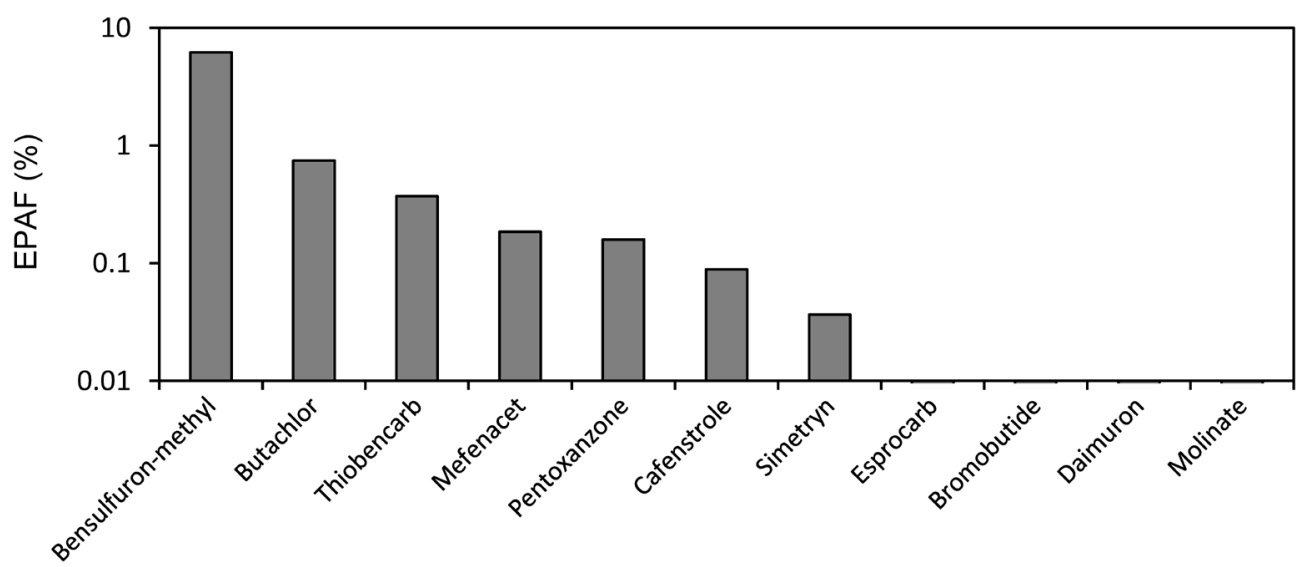

Fig. 6. EPAF for 11 herbicides. 
ばらつき加減を見たい場合には，リスクカーブによるリスク の表現が適している一方で, リスクを一つの数字にまとめて 比較したい場合にはEPAFによる表現がわかりやすい.11種 の水稲用除草剂の EPAFはFig. 6のようになり, リスク比較 に有用な手法として示すことができた。

\section{3. 確率論的リスク評価の活用}

確率論的リスク評価の現時点での利用方法は冒頭に記した ように，あくまでも効率的なリスク管理対策を考えるうえで 有用であるもので，值がいくつ以下であれば安全，いくつ以 上なら危険，などの判断に用いるものではない。さらにはリ スクランキングを作成することだけが目的でもないことに留 意が必要である。リスクの大きさを定量化することで，例え ば水管理の変更などのリスク低減対策を実行する際に，元の リスクがどの程度でそこからどの程度リスクが下がるかが明 確になり，環境保全効果をよりアピールしやすくなる。その ような評価がなければ，ただいたずらに生産者に対策費用を 負わせるだけのものとなってしまう。さらに，実際のリスク 管理の場面では様々なトレードオフ関係を考慮する必要があ るため, 本研究の成果はこのようなトレードオフ関係を見え る化するうえでも，有用なツールとなることが期待される.

ある特定の農薬のリスクのみを評価して，何かの判断をす ることも誤った判断につながる。ある特定の農薬を削減した だけではリスクが減るわけではない，評価していない他の農 薬に単純な切り替えが起こった場合に, リスクが下がるのか どうかは明らかではなく，むしろ増えてしまう場合もある。 また，たとえリスク比較の結果を踏まえてリスクの低い農薬 に切り替えても，その農薬に使用が集中すれば，その農薬に よるリスクが上昇してしまう。リスクの定量的な評価とは, このようにどんな管理をすればどのようなことが起こるの か，ということを考えるためのツールである．恣意的に選定 した農薬のみのリスク評価結果に基づいて農薬を禁止したり する，というのは意図するところと全く正反対である.

\section{3. 毒性データベースの構築と SSD}

\section{1. 毒性データベースの作成}

SSD解析に必要なデータ数（種数）は各国のガイドライン 等によって若干異なり，オランダでは 4 種類以上，デンマー クとオーストラリアと OECDでは 5 種類以上，米国では 8 種 以上，EUでは 10 種類以上となっている ${ }^{19)}$ 。様々な文献検討 の結果，5種のデータを用いた SSD はお抽そ妥当であるこ とが支持されている ${ }^{19,20)}$. 農薬の場合は前述のように，感受 性の高い分類群のデータで解析する必要がある.すなわち, 殺虫剂の場合は節足動物で 5 種以上，除草剂の場合は藻類で 5 種以上の毒性データが必要となる。殺菌剤の場合は分類群 と感受性の関係が明確ではないため，すべての水生生物で 5 種類以上のデータが必要とみなす。ただし，このようなデー
タが揃う農薬はほとんどなく，2章で示したような確率論的 リスク評価を幅広い農薬で行うためには, そもそもの毒性 データの整備自体が大きな課題となった。

日本国内における農薬使用の特徴として，水稲用農薬の使 用が多いことが挙げられる。特に水稲用除草剂は日本独特の ものが多く，欧米での使用がほとんどないことから生態毒性 データの蓄積が少ない。一方, 水稲用農薬を対象とした日本 国内での毒性試験の和文文献などは海外のデータベースには 採用されにくく，これらの毒性データベースの整備は遅れて いる。そこで筆者は，日本で主に使用されている水稲用農薬 を対象とした生態毒性データベースの構築を行ってきた ${ }^{21)}$. 本データベースの構築に当たってはSSDの活用を念頭に置 いているため, なるべく多種類の生物のデータを収録するよ うにしている，データの収集にあたっては，データの信頼性 の確保が重要である。そこで, すべての得られたデータにつ いては, OECDの高生産量化学物質点検マニュアルに従っ て，以下のように4段階の信頼性スコアを付けた：1信頼性 有り，2信頼性有り（制限付き），3信頼性なし，4評価不能. 特に, 原著論文などの各種文献の毒性試験データの信頼性の 評価はHobbs et al. ${ }^{22)}$ に従いスコア法によって行った.

収録データは，2017年 5月の時点で 2563 レコード（殺虫 剂 1455, 殺菌剂 176, 除草剂 932）を収録し, 農薬数は 82 種 類（殺虫剂 35 , 殺菌剂 9 , 除草剂 38）である. 生物の分類群 別（総生物種数は216種）に見ると，藻類と水草を合わせた 一次生産者で585レコード, 甲殼類と水生昆虫を合わせた水 生節足動物が 1104 レコード, 魚類と両生類を合わせた脊椎 動物が 678 レコード, その他 (貝類, 貧毛類, 繊毛虫類, ワ ムシ類，ヒル類など）が196レコードである.

\section{2. 節足動物の標準データセット}

農林水産省の試験ガイドライン ${ }^{23 ）}$ では，水生節足動物に ついてはオオミジンコを始め，ヨコエビ， ヌカエビ，ユスリ カ幼虫を用いた室内急性毒性試験のガイドラインがある。ま た，農業環境技術研究所では水生昆虫のコガタシマトビケラ を用いた毒性試験のマニュアル 24) を作成し, 殺虫剂に対す る感受性のデータを蓄積している。したがって，この5種の 水生節足動物については, 信頼性の高いデータを幅広い農 薬について揃えることができる状態にある．筆者はこの 5 種 のデータを用いて推定したSSD を標準SSD とすることを提 案している。節足動物で十分な数（10属以上）のデータが 揃っており，なおかつ標準5種のデータが揃っている 11 種 の殺虫剂を検討対象とし, 得られたすべての節足動物のデー タを用いて推定したSSD（これを真のSSD と仮定する）と， 標準 5 種のデータのみを用いて推定したSSD とを比較した結 果，両者はその形状に大きな差はなかったことを確認してい る $^{25)}$. 


\section{3. 藻類の標準データセット}

藻類の試験生物種についてもSSD解析のための標準デー タセットとして, 生態学的重要性を考慮して5種類を選定し た．生態学的重要性については，(1）日本の河川生態系に幅 広く分布しよく観察されるもの；(2) 幅広い分類群（珪藻, 緑藻，シアノバクテリアなど）をカバーし，現実的な種構成 （珪藻が優占）を反映すること；（3）好清水性種や好污濁性 種など，様々な環境条件をそれぞれ好む種を含むこと，を考 慮した。日本における付着藻類の調査結果などから, 緑藻 1 種 (Desmodesmus subspicatus), 珪藻3種 (Achnanthidium minutissimum, Nitzschia palea, Navicula pelliculosa)，シアノ バクテリア1種（Pseudanabaena galeata）を河川付着藻類の 代表として選定した ${ }^{20)}$. 試験生物種の選定に加えて，この 付着藻類 5 種を効率よく同時に試験するための簡便な試験方 法も開発した。これは，培養チャンバーとして通常使用され る三角フラスコの代わりに96穴マイクロプレートを使用し， 各ウェルの底面に藻類を付着させて培養を行い, 蛍光マイク ロプレートリーダーを用いて藻類バイオマスの測定を底面に 付着させたままで行う方法である ${ }^{20)}$ 。この試験方法の詳細 なマニュアルが農業環境技術研究所より公表されている26). この 5 種同時毒性試験を行うことで，効率よくSSD解析のた めのデータを得ることが可能である.

新たに開発した試験法を用いて，除草剂20種の毒性試験 を行ったところ，藻類の中でどの種に毒性が高いかは作用機 作特異的である，という結果が得られた（Table 1) 27 ．つま
り，除草剤で標準緑藻のみのデータに基づいたリスク評価を 行うと，リスクを見誤ってしまうことが示唆された。また， 複数の除草剂で藻類種間の感受性差が 1000 倍以上にもなっ ていることも明らかとなった。

\subsection{SSD 解析の対象農薬の拡大}

これまで述べたように，SSD解析のためのデータ整備の体 制を整え, 結果として現在までに68種類の代表的な水稲用 農薬のSSDを構築しており, 生態リスクを迅速に評価でき る状況にある ${ }^{25)}$. この 68 農薬で水稲用農薬の出荷量の大部 分をカバーできているが，それでも全登録農薬数に比べる とわずかな数である。そこで, SSD解析に必要な数のデータ がない場合においても，単一種の毒性データからSSDを推 定する手法を開発した ${ }^{28)}$. 多くの化学物質のSSD の解析を 行った結果, SSD の傾きは作用機作特異的であることが知ら れている。これを応用し，同じ作用機作間においては（1） SSD の傾き（対数標準偏差）は平行である；（2）種間の感 受性の順序は同じである；という二つの仮定を置くことで, たった一種類の標準種の毒性データのみから SSDを外挿推 定することが可能となる。この推定法の検証として, 推定法 の開発に用いたデータとは別の毒性データセットを用いて, 推定したSSD と実際のSSD を比較した結果，お打む称同様 の結果が得られたことが確認されている ${ }^{28)}$ 。この方法を用 いることで，現在ほとんどの農薬についてSSDを用いたリ スク評価が可能な状況にある.

Table 1. Comparative toxicity $\left(\mathrm{EC}_{50}, \mu \mathrm{g} / \mathrm{L}\right)$ of 16 herbicides to 5 periphytic algae and the relationship with mode of action $(\mathrm{MoA})^{a)}$

\begin{tabular}{|c|c|c|c|c|c|c|}
\hline Herbicide & $\mathrm{MoA}^{b)}$ & Pse & Des & Ach & Nit & $\mathrm{Nav}$ \\
\hline bensulfuron-methyl & $\mathrm{B}$ & 4.1 & 150 & $>6000$ & $>6000$ & $>6000$ \\
\hline cyclosulfamuron & $\mathrm{B}$ & 3.1 & 11 & $>9700$ & $>9700$ & $>9700$ \\
\hline pyrimisulfan & $\mathrm{B}$ & 150 & 120 & $>5400$ & 4400 & $>5400$ \\
\hline simetryn & $\mathrm{C} 1$ & 23 & 16 & 47 & 86 & 34 \\
\hline pentoxazone & $\mathrm{E}$ & $>220$ & 0.084 & $>220$ & 5.7 & 59 \\
\hline pyraclonil & $\mathrm{E}$ & $>5000$ & 0.96 & 1300 & 58 & 1000 \\
\hline oxadiargyl & $\mathrm{E}$ & $>1500$ & 0.21 & 840 & 56 & 380 \\
\hline tefuryltrione & F2 & $>100,000$ & $>100,000$ & 10,000 & 23,000 & 23,000 \\
\hline benzofenap & F2 & $>240$ & $>240$ & 130 & 66 & 15 \\
\hline pretilachlor & K3 & $>4000$ & 62 & 5100 & 15,000 & 1300 \\
\hline butachlor & K3 & $>3600$ & 38 & 5100 & 6200 & 950 \\
\hline mefenacet & $\mathrm{K} 3$ & $>10,000$ & 620 & $>3000$ & $>3200$ & 5800 \\
\hline cafenstrole & K3 & $>11,000$ & 8.3 & 8600 & 5700 & 9500 \\
\hline fentrazamide & K3 & $>4100$ & 50 & 11,000 & 3600 & 55,000 \\
\hline benfuresate & $\mathrm{N}$ & $>23,000$ & 22,000 & 10,000 & 76,000 & 95,000 \\
\hline esprocarb & $\mathrm{N}$ & 1600 & 350 & $>3200$ & 4100 & 1800 \\
\hline
\end{tabular}

\footnotetext{
a) Pse: Pseudanabaena galeata; Des: Desmodesmus subspicatus; Ach: Achnanthidium minutissimum; Nit: Nitzschia palea; Nav: Navicula pelliculosa;

${ }^{b)} \mathrm{B}$ : inhibitor of acetolactate synthase; C1: inhibitor of photosynthesis by photosystem II; E: inhibitor of protoporphyrinogen oxidase; F2: inhibitor of 4-hydroxyphenyl-pyruvate-dioxygenase; K3: inhibitor of very long-chain fatty acid synthesis; N: inhibitor of lipid synthesis.
} 


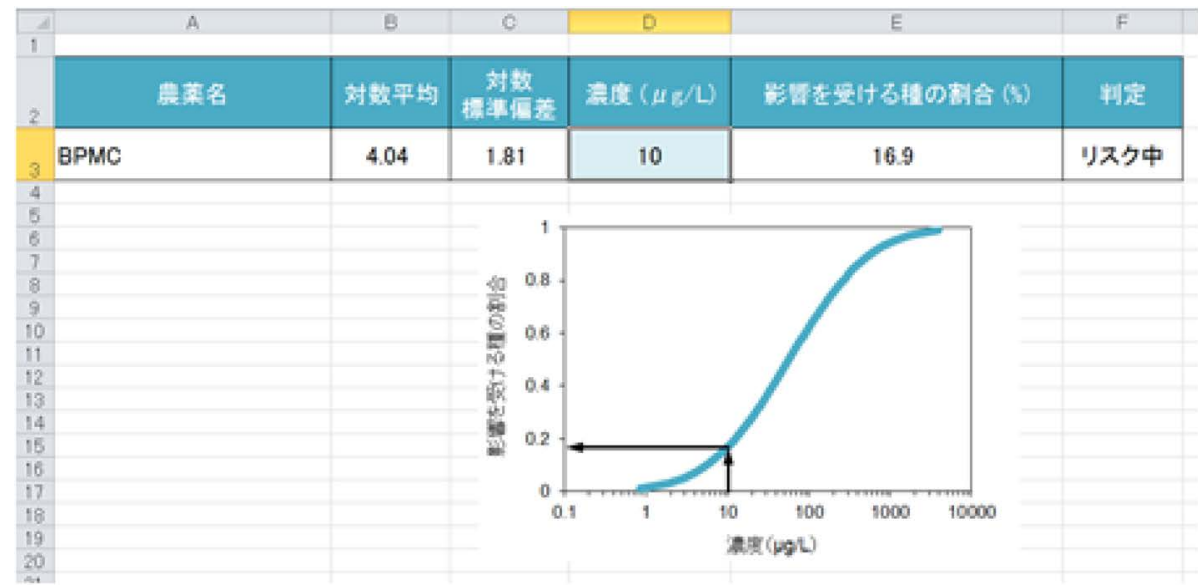

Fig. 7. Microsoft Excel worksheet for calculation of PAF (in Japanese only). SSD parameters for 68 pesticides are already inputted, and PAF can be calculated by selecting pesticide name and inputting environmental concentration $(\mu \mathrm{g} / \mathrm{L})$. Moreover, evaluation of PAF values (4 classes) is also shown as reference.

\section{4. 種の感受性分布の活用}

\subsection{SSDマニュアルの公開}

SSD解析の手法は, 日本国内では研究者の間でもあまり知 られておらず，これまで活用事例は限られていた。この理由 として, 解析手法を詳しく解説した日本語の文献がほとんど ないことが考えられた。そこで，日本国内でのSSDを用い た生態リスク評価の活用に向けて，「技術マニュアル】農 薬の生態リスク評価のための種の感受性分布解析」を公開し た ${ }^{29)}$ 。これは，これまで行ってきたSSDに関する技術的な 検討結果を，手法の基本的な紹介や歴史的背景，海外での活 用事例などと共にまとめたものであり，農業環境技術研究所 のウェブサイト（http://www.niaes.affrc.go.jp/techdoc/ssd/) から，マニュアルと解析ッール（MS-Excel用ファイル）を ダウンロードできる．特徴としては，統計の専門知識がなく ても簡単にSSD の解析や生態リスク評価ができるッールも 併せて公開した点にある。このッールを用いると，環境中農 薬濃度の推定值やモニタリング結果を入力するだけで生態り スク評価が可能となったり（Fig. 7)，手持ちの毒性データを 入力して，SSD解析を行なったりすることが可能である．さ らに，曝露の分布に関する情報を入力して, EPAF（Fig. 5) の計算を行うことも可能である。

\section{2. 登録保留基準の妥当性の検証}

1 章で述べた水産登録保留基準の妥当性を検証するため に，これまでに解析した 68剂のSSDから計算された予測無 影響濃度 $\left(\mathrm{HC}_{5}\right)$ と水産登録保留基準值とを比較した ${ }^{25)}$. 68 農薬のうち 50 農薬は両者の差が 10 倍以内であり同程度 と判断された。つまり, 多くの農薬については現行の水産 登録保留基準值で $\mathrm{HC}_{5}$ と同程度の安全性が担保されている ことになる。しかしながら，残りの18農薬（9殺虫剂 +9 除
草剂）で，水産登録保留基準は $\mathrm{HC}_{5}$ よりも 10 倍以上高く, 当時の制度ではリスクが過小評価されていると判断された (Fig. 8).さらに，これらの18農薬は, 殺虫剤ではフェニル ピラゾール系，ネオニコチノイド系，スピノサドの系統，除 草剂ではアセ卜乳酸生合成阻害系, プロトポルフィリノーゲ ンオキシダーゼ阻害系, 4-ヒドロキシフェニルピルビン酸ジ オキシゲナーゼ阻害系であり, 特定の作用機作に偏ることが 明らかとなった。この比較が示唆することは，指標生物 3 点 セットで生態影響を評価することの限界性である．その後, 水産登録保留基準の制度において, 上記3系統の殺虫剂で は3種の試験生物のデータに加えてユスリカ幼虫の毒性試験 データの提出が必須となったところである ${ }^{30)}$.

さらに Nagai ${ }^{25)}$ は水産登録保留基準の濃度を，SSDを用い

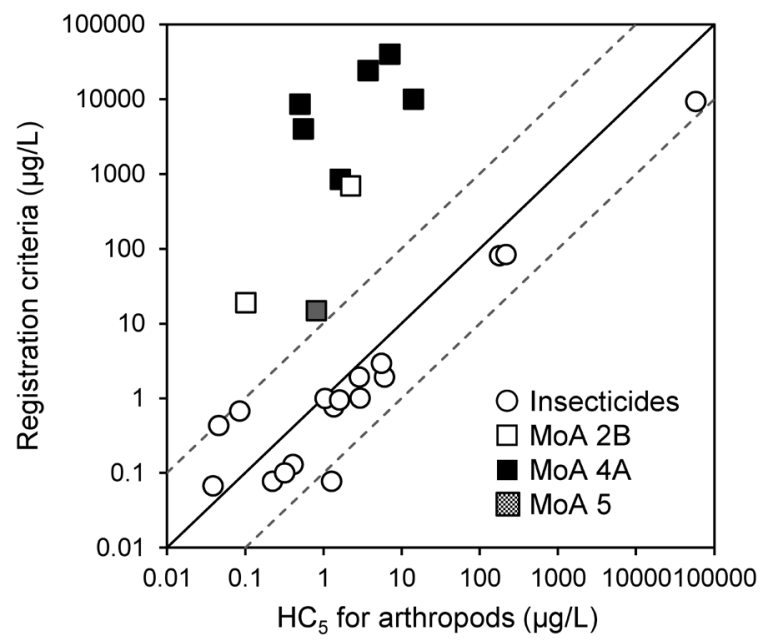

Fig. 8. Comparison between $\mathrm{HC}_{5}$ and registration criteria for 26 insecticides. The solid lines show $1: 1$ and dotted lines show $1: 10$ and $10: 1$. Mode of action $(\mathrm{MoA})$ indicates the classification by Insecticide Resistance Action Committee. 
て影響を受ける種の割合に換算するとどのような值になる かを計算した。結果は $0.1 \%$ 未満から $90 \%$ 以上まで様々であ り，中央值はちょうど5\%であった。つまり，水産登録保留 基準は無影響を意味するものではなく，また一定の影響しべ ルを示すものではない，ということが示された。

\section{おわりに}

以上に述べてきたように，SSD は生態リスク評価において 非常にパワフルなツールである。様々な注意点があるもの の，それでもより適切なリスク管理を可能とする非常に有益 な情報を与えてくれるだろう。今後の展望としては，対象と する生物種の拡大や野外生態調査によるリスク評価の検証が 挙げられる。これまでSSD解析の対象となってきた生物種 は魚類，節足動物，藻類に偏っている．感受性の種間差をよ り適切に表現するためには，水生菌類や水草等の維管束植 物，土壌動物などこれまでデータの蓄積のない生物種への 拡大が望まれる。また，例えば「10\%の種に影響が出る」と いう計算がなされた場合に実際の生態系に何が起こるのか? といった生態学的な意味づけについては現時点では不明確で ある。このようなリスク評価と実際の生態系の応答との関係 を築くことは今後の重要な課題となるであろう。この課題に ついての近年の動向については，すでに別のレビュー ${ }^{31)} て$ も論じているので，そちらを参照いただきたい．

\section{謝辞}

このたび栄誉ある奨励賞を授賞いただき，日本農薬学会の 関係者に厚く御礼を申しあげたい，本研究は，農業のことも 農薬のことも全くのど素人であった筆者が独立行政法人農業 環境技術研究所に採用された後，新たに自分で立ち上げて 10年ほど行ってきた研究の成果をまとめたものである。こ の間日本農薬学会の場において農薬科学を勉強する機会を 多々頂いた．今後も学術面での貢献で恩返しをしたい。ま た，農環研での研究は多くの共同研究者の手助けを借りて進 めることができた．特に多大な協力をいただいた上路雅子元 理事, 與語靖洋生物多様性研究領域長, 大谷卓元有機化学物 質研究領域長, 稲生圭哉化学物質影響評価ユニット長, 堀 尾剛博士，横山淳史博士，岩船敬博士，岩崎亘典博士，そ乙 て契約職員の方々にこの場を借りて感謝の意を表す。さら に，本研究は環境省環境研究総合推進費「適切なリスク管理 対策の選択を可能にする農薬の定量的リスク評価法の開発 （C-1102）」（平成23～25年度）と，環境省委託事業「農薬水 域生態リスクの新たな評価手法開発事業」(平成23～27年度) の成果の一部をまとめたものである.これらの研究資金のお かげで飛躍的に研究が発展した。ただし，本内容については 環境省の見解ではなく，筆者の責任において取りまとめたも のであることを付す.

\section{引用 文 献}

1）永井孝志：日本リスク研究学会誌 23, 145-152 (2013).

2）環境省：“水産動植物の被害防止に係る農薬登録保留基準とし て環境大臣の定める基準の設定に関する資料," http://www.env. go.jp/water/sui-kaitei/kijun.html (Accessed 26 May, 2017)

3) T. Nagai and A. Yokoyama: J. Pestic. Sci. 37, 233-239 (2012).

4) J. Caines Jr:: Bioscience 36, 670-672 (1986).

5) L. Posthuma, G. W. Suter and T. P. Traas (eds.): "Species Sensitivity Distributions in Ecotoxicology (Environmental and Ecological Risk Assessment)," Lewis Publisher, Boca Raton, USA, 2001.

6) U.S. EPA: "Guidelines for Deriving Numerical National Water Quality Criteria for the Protection of Aquatic Organisms and Their Uses," U. S. Environmental Protection Agency, 1985.

7) EC: "Technical Guidance for Deriving Environmental Quality Standards," European Commission, 2011.

8) ANZECC: "Australian and New Zealand Guidelines for Fresh and Marine Water Quality," Australian and New Zealand Environment and Conservation Council, 2000.

9) L. Maltby, N. Blake, T. C. M. Brock and P. J. van den Brink: Environ. Toxicol. Chem. 24, 379-388 (2005).

10) P. J. van den Brink, N. Blake, T. C. M. Brock and L. Maltby: Hum. Ecol. Risk Assess. 12, 645-674 (2006).

11) L. Maltby, T. C. M. Brock and P. J. van den Brink: Environ. Sci. Technol. 43, 7556-7563 (2009).

12) R. P. A. vanWijngaarden, L. Maltby and T. C. M. Brock: Pest Manag. Sci. 71, 1059-1067 (2015).

13) European Food Safety Authority: "Guidance on Tiered Risk Assessment for Plant Protection Products for Aquatic Organisms in Edge-of-field Surface Waters," EFSA Journal, 2013: 11, 3290, 2013.

14) 永井孝志, 稲生圭哉, 堀尾 剛：農薬誌 33, 393-402 (2008)。

15) J. M. Giddings, L. W. Hall Jr. and K. R. Solomon: Risk Anal. 20, 545-572 (2000)

16) D. R. J. Moore, R. P. Thompson, S. I. Rodney, D. Fischer, T. Ramanarayanan and T. Hall: Integr. Environ. Assess. Manag. 6, 102118 (2010).

17) K. R. Solomon, D. B. Baker, R. P. Richards, K. R. Dixon, S. J. Klaine, T. W. La Point, R. J. Kendall, C. P. Weisskopf, J. M. Giddings, J. P. Giesy, L. W. Hall Jr. and W. M. Williams: Environ. Toxicol. Chem. 15, 31-76 (1996).

18）永井孝志, 稲生圭哉, 横山淳史, 岩船 敬, 堀尾 剛：日本リス ク研究学会誌 20, 279-291 (2010).

19) P. L. TenBrook, R. S. Tjeerdema, P. Hann and J. Karkoski: Rev. Environ. Contam. Toxicol. 199, 19-109 (2009).

20) T. Nagai, K. Taya, H. Annoh and S. Ishihara: Ecotoxicol. Environ. Saf. 94, 37-44 (2013).

21）永井孝志：インベントリー 11, 58-69 (2013).

22) D. A. Hobbs, M. S. J. Warne and S. J. Markich: Integr. Environ. Assess. Manag. 1, 174-180 (2005).

23）農林水産省：農薬の登録申請に係る試験成績について（平成 12 年11月 24 日付け 12 農産第 8147 号農林水産省農産園芸局長通 知), 2000

24）農業環境技術研究所：コガタシマトビケラ 1 齢幼虫を用いた農薬 の急性毒性試験法マニュアル, 2008 
25) T. Nagai: J. Pestic. Sci. 41, 6-14 (2016).

26）農業環境技術研究所：河川付着藻類を用いた農薬の毒性試験マ ニュアル, 2014.

27) T. Nagai, K. Taya and I. Yoda: Environ. Toxicol. Chem. 35, 368-375 (2016).

28) T. Nagai and K. Taya: Environ. Toxicol. Chem. 34, 677-684 (2015).

29）農業環境技術研究所：【技術マニュアル】農薬の生態リスク評価 のための種の感受性分布解析, 2016.

30）環境省：“環境大臣が定める水産動植物の被害防止に係る農薬 登録保留基準の設定における種の感受性差の取扱いについて (案),” 平成 28 年 3 月 3 日中央環境審議会土袞農薬部会農薬小委 員会（第50回）資料, 2016.

31）永井孝志：農薬誌 42, 133-137 (2017).

\section{略 歴}

永井孝志（ながい たかし）

生年月日：1976年11月30日

最終学歴：筑波大学大学院博士課程生命環境科学研究科修了

研究テーマまたは主な職歴: 生態毒性学, リスク評価, レ ギュラトリーサイエンス

趣味：旅行, 子供と遊ぶこと 